\title{
Negative Changes on Culture and Livelihoods of Xinh Mun Ethnic Group (Case Study in Chieng so Commune, Dien Bien Dong District, Dien Bien Province, Vietnam)
}

\author{
Duong Van Son* \\ Faculty of Agricultural Economics \& Rural Development, Thai Nguyen University of Agriculture and Forestry \\ (TUAF), Thai Nguyen pprovince, Vietnam
}

*Corresponding Author: Duong Van Son, Faculty of Agricultural Economics \& Rural Development, Thai Nguyen University of Agriculture and Forestry (TUAF), Thai Nguyen pprovince, Vietnam

\begin{abstract}
In the process of global integration and and market economy, currently cultures and livelihoods of the Xinh Mun, a minority ethnic group living at the Chieng So commune (Dien Bien Dong district, Dien Bien province) have been changing in negative dimension such as high illiteracy rate (57.95\%), high poverty (68.18\%), low income (2.81 million VND or 126 USD per person per year), high disparity between the rich and the poor of the Xinh Mun community (7.94 times), narrow living, resident and cultural space,... Their agricultural livelihoods are considered as unsustainable and could not satisfy the food demand of the community. It has tendency to depend on external factors not only are input materials, science and techonology but also consumption markets. Habitat loss, material and cultural life of the Xinh Mun ethnic group is going to be at the red line and there is a need to have urgent interventions or projects for making a positive change, ensuring material and cultural life of mentioned Xinh Mun ethnic group.
\end{abstract}

Keywords: Livelihoods; Culture; Cultural Change; Livelihood Change

\section{INTRODUCTION}

Cultural and livelihood changes is considered as an inevitable process of socio-economical development. Culture change is a term used in public policy making that emphasizes the influence of cultural capital on individual and community behavior (Hoang Cam, Pham Quynh Phuong, 2012). It places stress on the social and cultural capital determinants of decision-making and the manner in which these interact with other factors like the availability of information or the financial incentives facing individuals to drive behavior. Livelihood change is considered as in opposite direction with sustainable livelihoods, aimed at the change of livelihoods differing with previous livelihoods. Under the impacts of external factors and time flow, culture and livelihoods of any community trend towards change in positive or negative directions, up to specific conditions.

Xinh Mun is a minority ethnic group living at West-Northern region of Vietnam, focusing on 2 provinces of Son La and Dien Bien. They are based on the mountains or mountainsides alongside the Vietnam - Laos border. Their life is based on subsistence livelihoods, leading towards their decrease in culture is becoming a serious problem, affecting the conservation the value of their culture. The objectives of the research is to examine the current situation on culture and livelihoods of Xinh Mun ethnic group, identify negative changes on their culture and livelihoods as database for proposed interventions or projects aimed at the conservation of indigenous culture and livelihoods, enhancement and improvement of material life of the Xinh Mun minority ethnic group.

\section{Data Collection}

The research covers the community of the Xinh Mun minority ethnic group, including 202 households with 1,015 people, living at Chieng So commune, Dien Bien Dong district, West-Northern Dien Bien province of Vietnam.

The main content of the research are: (1) Current situation on culture of Xinh Mun community at Chieng So commune, Dien Bien Dong district, (2) Current status on livelihoods of Xinh Mun community at Chieng So commune, Dien Bien Dong district, Dien Bien province. 
Three primary methods are adopted for data collection in the research, including direct observation, expertise consultation and survey questionnaire. Twenty-two households in every four villages namely $\mathrm{Na}$ Ly, Co My, Keo Lua and Hin Ong were surveyed, made up the sample size of 88 in total.

Data was analyzed by Excel-PivotTable. Statistical analysis of the sample is used by some common statistical quantities such as Standard Deviation (Std Dev or SD), Mean, Standard Error (SE), Coefficient of Variation (CV\%).

\section{RERULTS AND DISCUSSIONS}

\subsection{Some Currently Characteristics on Culture of Xinh Mun Ethnic Group}

Surveyed results shown that (Table 1): The current education level of Xinh Mun people at Chieng So commune is very low, resulting in their high illiterate rate. Among total of 88 sampled households at four villages of Chieng So commune, there are 51 household heads in an illiteracy, occupies $57.95 \%$. There are 37 household heads (occupies 42.05\%) in literacy with their education level of 4.5 in 12 grade system, including preliminary school, secondary school and high school. The education level of the non-poor households is 4.6, higher than that of poorest groups. Furthermore, with 37 sampled literate households, the standard deviation (SD) is 2.9 and the coefficient of variation $(\mathrm{CV} \%)$ is $63.1 \%$, means that coefficient of variation of education level is more likely to be high with standard error (SE) of 0.5 .

Generally, there is a relationship between household wealth and illiteracy rate. Consequently, if the poor household wealth is, the low illiterate rate has. High illiteracy rate and low education level are acknowledged as two critical determinants on culture of the Xinh Mun ethnic group living at Chieng So commune. It said that the problem is not only the illiteracy rate but also the poverty status that need to take into account. As we can also be seen from the Table 1 that the percentage of sampled poorest households $(68.18 \%)$ is higher than the commune's average. There are 4 less poor households (occupies $4.55 \%$ ) and 24 non-poor households, occupies $27.27 \%$. As a result, poverty is a serious problem, threaten the life of Xinh Mun community living at Chieng So commune. Poverty-stricken, high poorest rate and other causes are likely to be a big concern of Xinh Mun people living in Chieng So commune.

Traditional residence of Xinh Mun focused on family groups or villages based on natural space such as mountains, hillcrest, forests with water fall, water mouth or source for drinking, nearby mountains and forests before, but now they are replaced by a small houses located along the road, far away from the water source without forest and tree, isolated and solitary location at the midway of the bare mountains or mountainsides without any trees. Traditionally, resident space of Xinh Mun before is mountain, forestry, forest, valley, stream, water fall,... But now there is no forest, no tree, no water fall, bare monutain instead,... The limitation of resident space has made the Xinh Mun ethnic groups to become more poor. Narrow living and resident and cultural space, a core cause of degression, is one of the key problem of Xinh Mun ethnic group there.

Table1. Percentage of household wealth ranking, literacy and knowledge level

\begin{tabular}{|l|l|l|l|}
\hline $\begin{array}{c}\text { Household wealth } \\
\text { ranking }\end{array}$ & \multicolumn{1}{|c|}{$\begin{array}{c}\text { Percentage of households } \\
(\mathbf{\%})\end{array}$} & $\begin{array}{c}\text { The literacy rate } \\
(\mathbf{\%})\end{array}$ & $\begin{array}{c}\text { Education level } \\
\text { (grades) }\end{array}$ \\
\hline Poorest & 68.18 & 35.0 & 4.5 \\
\hline Less poor & 4.55 & 50.0 & 4.5 \\
\hline Non-poor & 27.27 & 58.3 & 4.6 \\
\hline
\end{tabular}

The semi-resident preliminary school and secondary school at the commune (a school where pupils often go to in the early morning, being offerred a free lunch and leave at the late afternoon) include 348 pupils, of which 130 are Xinh Mun, occupies 37.4\% of the total. The school has 10 classrooms with 24 school teachers and anybody are Xinh Mun teacher. This is one of the constraint influencing to the learing process of Xinh Mun pupils. According to school teachers (Table 2), learning outcome and moral train of Xinh Mun pupils is worst (mark 3) compared with Mong (mark 2) and Thai pupils (mark 1). According to some researches (Nguyen Van Manh, 2009; Chu Thuy Lien, 2013; Ngo Quang Son, 2014), confident loss of Xinh Mun ethinic group seems to be as their habit during they are still as pupil of the preliminary school and secondary schools. The Xinh Mun ethnicity group may recognize their relatively backward or maybe believed in that point. As a result, this point leads Xinh 
Mun school pupils have on voice during their pupil life. In addition, acompanying with eagerly expectation from external support and preconceptions or social stigma of outsiders have been growing as barries effecting to the Xinh Mun community development. On another hand, their inferiority or complex, low voice in social community could be able to become from two directions: (1) The Xinh Mun people, and (2) Environment, as thay cannot create a suitable environment for them could be able to self-control and coordinate their resources and community development in order to selfdefence and protect such shocks come from outside.

Accoording to Chieng So commune people board, at the movement, there is no commune cultural house either village cultural house, therefore almost villagers mitting and training are normally taken place at the village head-man. There is no cultural space, where may have limited partly cultural activities, especially traditional cultural actitities of Xinh Mun ethnic group.

Table2. Learning outcome of Xinh Mun pupils in compared with others ( 1 is best, 3 is worst)

\begin{tabular}{|l|c|c|c|}
\hline \multicolumn{1}{|c|}{ Criteria } & Xinh Mun & Mong & Thai \\
\hline Learning outcome & 3 & 2 & 1 \\
\hline Moral train & 3 & 2 & 1 \\
\hline
\end{tabular}

Xinh Mun's culture can be improved by their consumption and use of communication and transport means that they have been accessing. According to our surveyed result at 4 villages of Co My, Hin Ong, Keo Lua and $\mathrm{Na} \mathrm{Ly,} \mathrm{all} \mathrm{these} \mathrm{four} \mathrm{villages} \mathrm{consit,} \mathrm{in} \mathrm{total} \mathrm{of} 122$ sample households, $64.2 \%$ of whom owns television (64.2\% of total households), $75.7 \%$ of those have a cellphone. With regard to motorbike, a key transport mean, $73.5 \%$ of the total households have their own motorbike. It means that, together/along with the improvement of rural infrastructure, the transportation and communication means have also been enhancing among the Xinh Mun ethnic group to meet the demand of cultural consumption. This is an example for the possitive change on culture of Xinh Mun community in the research.

\subsection{Curent Xinh Mun's Livelihood}

Basically, Xinh Mun ethnic group's livelihoods analysis at Chieng So comprises five key components: human capital, financial capital, natural capital, physical capital, and social capital. Typically, their livelihoods have been improving not only in quality, but also in quantity, mostly based on the upgrade of rural infracstructure and living standard of Xinh Mun households.

Table3. Number of labour and member family of Xinh Mun

\begin{tabular}{|l|l|l|}
\hline \multicolumn{1}{|c|}{ Household wealth ranking } & Labors per household & Persons per household \\
\hline Poorest & 2.4 & 5.0 \\
\hline Less poor & 2.0 & 5.5 \\
\hline Non-poor & 2.9 & 5.9 \\
\hline
\end{tabular}

Regarding to the human capital, among total of 88 surveyed households, there are on average of 2.5 labours and 5.3 people per household, indicating that human resource has no reason to concern to Xinh Mun ethnic group (Table 3).

The natural capital includes land, water resource, forest, etc... Surveyed data suggests that there is a growing burden in respect of scarcity and the size of the local natual capital. Specifically, each household have only 2,964 metter square of arable land, each Xinh Mun households have 5.3 people on average, therefore a single person have only 559 metter square of land for cultivationwhich is a very small number. Moreover, the distribution of arable land did not balance among household groups, leave the poor behind as they have less land to cultivate. Consequently, land cultivation distibuting for the poorest, the less poor and the nonpoor household are $4,080 \mathrm{~m}^{2}, 3,575 \mathrm{~m}^{2}$ and 2,476 $\mathrm{m}^{2}$, respectively. Notwithstanding, with SD is $1,750 \mathrm{~m}^{2}$ and $\mathrm{SE}=187 \mathrm{~m}^{2}$, meaning that the variation of cultivation land seems to be high (Table 4). The limitation and scarcity of cultivation land, a specific mean of farming production, is considered as a crucial cause of poverty among Xinh Mun ethnic group.

The restraint of cultivation land, the unavailability of forest, soil erosion and degression are currently a picture of research site. According to surveyed result, 88 sampled households also have no forest lands, no household forests, no community forests as well as other lands for production. The scarcity and low quality of natural capital is also a reason explains that why they are poor. 
Negative Changes on Culture and Livelihoods of Xinh Mun Ethnic Group (Case Study in Chieng so Commune, Dien Bien Dong District, Dien Bien Province, Vietnam)

Table4. Farming area and income of Xinh Mun households

\begin{tabular}{|l|l|l|l|l|}
\hline $\begin{array}{c}\text { Household wealth } \\
\text { ranking }\end{array}$ & \multicolumn{1}{|c|}{$\begin{array}{c}\text { Farming area } \\
\left(\mathbf{m}^{\mathbf{2}} / \mathbf{H H s}\right)\end{array}$} & $\begin{array}{c}\text { Cash income } \\
(\mathbf{m i l l} \text { vnd/hh/year })\end{array}$ & $\begin{array}{c}\text { On-farm } \\
\text { income } \mathbf{( \% )}\end{array}$ & $\begin{array}{c}\text { Off-farm income } \\
(\boldsymbol{\%})\end{array}$ \\
\hline Poorest & 2,476 & 11.542 & 94.5 & 10.7 \\
\hline Less poor & 3,575 & 17.750 & 100.0 & 0.0 \\
\hline Non-poor & 4,080 & 23.133 & 95.6 & 7.0 \\
\hline Mean & 14.985 & 95.0 & 9.5 \\
\hline$S D$ & 1,964 & 11.895 & 8.1 & 9.2 \\
\hline$S E$ & 1,750 & 1.268 & 0.9 & 1.4 \\
\hline$C V \%$ & 187 & 79.4 & 8.6 & 96.4 \\
\hline
\end{tabular}

Livelihood in crop production of local people consists of maize, paddy rice and upland rice. Of which, $100 \%$ surveyed households grow maize as their traditiional food crop with planting area of $1,477 \mathrm{~m}^{2} /$ household on average. Yet, the surveyed result suggests that the poor households have less maize planting area than their counterparts, indicating why they are in deficient and why they are poor. Nevertheless, maize is gluttonous crop that needs more nutrients, so farmers should apply chemical fertilizers caused soild degression. There are 53.4\% surveyed households grow paddy rice with planting area of $1,529 \mathrm{~m}^{2} /$ household on average. There are $18.2 \%$ surveyed households grow upland rice with planting area of $3,431 \mathrm{~m}^{2}$ per household. Actually, planting area of upland rice is higher more 2 times in comparison with maize and paddy rice, but its harvest is still low, even have no harvest due to it is up to rain and usally faces the drought. Obviously, crop livelihoods are poor, mostly are food crops with no vegetables or any other high-protein crops such as peanuts, soybean, sesame that used for daily nutrients consumption.

Xinh Mun's livestock livelihoods generally are still less developed in comparison with crop livelihoods, mainly follows extensive and unbrile forms such as goat, poultry, pig and fish. Pig is often in danger of disease as a consequence of raising near the road, where disease come from. Livelihood practices are often backwards, no or very limited in respect of input investment and the deficit of indigenous species. Livestock are traditionally kept in free grazing or controlled by stall nearby the house, or nearby the road where there is a potential risk of contamination or disease outbreak not only for livestocks, but also for people nearby. Livelihood limitations within remote areas, especially mentioned Xinh Mun ethnic group who have few alternative options available can be resulted by the process of socio-economical development in the global integration period and market economy (Tran Tien Khai, Nguyen Ngoc Danh, 2012). Therefore, it is needed to have urgent interventions for improving their livelihoods mostly based on indigenous knowledge.

Each household is 14.985 million vnd/year ( 1 USD $=22,200$ vnd), and has 5.3 persons on average. So that each person can earn more than 2.810 million vnd/year, too small amount. It is also worth to notice that there is an asymmetry in income among Xinh Mun groups. By this, the poorest has lowest income (11.542 million vnd/year/household), by a half of the non-poor (23.133 million vnd/year/household). Exceptionally, too high standard deviation ( $\mathrm{SD}=11.895$ million vnd) and high coefficient of variation $(\mathrm{CV}=79.4 \%)$, indicating that variation of income among Xinh Mun households is considerably high (7.94 times), generating the strong classification of income generation activities of Xinh Mun households living at Chieng So commune (Table 4).

There are $100 \%$ of households lived on on-farm income with averagely rate reaches $95 \%$, indicating that agriculture is mainly income source of Xinh Mun households. There are 46 households based on off-farm income, ocuppies $52.3 \%$ of the total surveyed households. On average, each household can earn 9.5\% income from off-farm activities, mostly in form of hired labor as employee. With high standard deviation $(\mathrm{SD}=9.2 \%)$ in compared with the mean $(9.5 \%)$, and the high value of the coefficient of variation $(\mathrm{CV}=96.4 \%)$, indicating that the variation of off-farm income is high $(9.64$ times) among 46 households who have off-farm generating income activities (Table 4).

Additionally, off-farm activities include hired labor (as employee), commune or village allowance (stipend) and labor export. Total off-farm income by cash earning is 1,207,647 vnd per household per month (1 USD $=22,200$ vnd). Notwithstanding, with too high standard deviation ( $\mathrm{SD}=2,002,262$ vnd), and high standard error ( $\mathrm{SE}=343,385 \mathrm{vnd})$, therefore coefficient of variation is high $(\mathrm{CV}=$ $165.8 \%$ ), demostrating that the variation of cash income from off-farm activities is too high among 
Xinh Mun households (16.58 times). In addtion, their income generation is unstable, mostly lived on hired labor (Table 5). Data illustrated that among surveyed households, there are 37 households in hired labor as emplyees, occupies $42.05 \%$ of total surveyed households. There are 2 households having village or commune allowance (working as partly local staff) and 1 household is in labor export (Table 5).

Table5. Off-farm activities and income of Xinh Mun households

\begin{tabular}{|c|c|c|c|c|c|c|c|}
\hline \multirow{2}{*}{$\begin{array}{c}\text { Household } \\
\text { wealth ranking }\end{array}$} & \multicolumn{2}{|c|}{ Employee } & \multicolumn{2}{|c|}{ Village/commune allowance } & \multicolumn{2}{|c|}{ Labor export } & \multirow{2}{*}{$\begin{array}{l}\text { Average income } \\
(1,000 \mathrm{vnd} / \mathrm{month})\end{array}$} \\
\hline & n & $\%$ & $\mathbf{n}$ & $\%$ & $\mathbf{n}$ & $\%$ & \\
\hline Poorest & 26 & 29.55 & 1 & 1.14 & 1 & 1.14 & $1,063.478$ \\
\hline Less poor & 1 & 1.14 & 0 & 0.00 & 0 & 0.00 & 300.000 \\
\hline Non-poor & 10 & 11.36 & 1 & 1.14 & 0 & 0.00 & $1,630.000$ \\
\hline Mean & & & & & & & $1,207.647$ \\
\hline$S D$ & & & & & & & $2,002.262$ \\
\hline$S E$ & & & & & & & 343.385 \\
\hline$C V \%$ & & & & & & & 165.8 \\
\hline
\end{tabular}

It can be said that, the Xinh Mun ethnic group is much likely to work as hired labor or employee due to their narrow/definite vision, but they did have a very limited and degressive natural resources. That is reason why they have to work as hired labors to earn money to buying food and covering other daily expenses. On-farm activities are mostly conducted and managed by women, creating a heavy workload for women as they not only have to work on-farm activities, but also work as housekeeping during their husbands or men did leave far away for earning money.

Apart from crops, livestocks and hired labors (as a mean of off-farm income activitiy), Xinh Mun people at Chieng So commune have no other livelihood activity. There is no activity on natural expoitation such as timber collection, non-timber collection or wood collection. The Mã river did become a dead river in winter and dry season. In rainy season the river did become red and dirt water without any fishs can be able to exist under that living condition. Famous handicrafts have been decreased and gradually disappeared,... The Xinh Mun agricultural livelihoods are considered as unsustainable, have very few alternative options available and could not satisfy the food demand of the community. It has tendency to depend on external factors not only are input materials, science and techonology but also consumption markets. Material and cultural life of the Xinh Mun ethnic group is at highest alarming level, giving a call to have interventions for the positive change.

\section{CONCLUSION}

In the global integration period and market economy, current culture and livelihoods of the Xinh Mun ethnic group at Chieng So commune (Dien Bien Dong district, Dien Bien province) have been changing in negative dimension. The average illiteracy rate of the Xinh Mun community has increased at a alarming level (57.95\%), poverty and high percentage of poor households $(68.18 \%)$, low income (2.81 million VND or 126 USD per person per year), the disparity between the rich and the poor in classification of the Xinh Mun community (7.94 times), narrow living, resident and cultural space,,.. acompanying with eagerly expectation from outside support and preconceptions of outsiders have been growing as barries effecting to the Xinh Mun community development. The livelihoods on crop production are considered as unsustainable livelihood strategies and poor diversity to which based mainly on food crops (maize, upland-rice, lowland-rice) without vegetables and highprotein crops such as soybean, peanuts or sesame. Livestock production (such as buffalo, cattle, goat) is going backward and unappropriate to current condition of the Xinh Mun site. Generally, agricultural livelihoods are unsustainable, few alternative options available, could not fulfil the food demand of the community, and tend to depend on external factors not only are input materials, science and techonology but also consumption markets. Except livelihood activities on crops, livestocks and hired labors as employees with few alternative options available, Xinh Mun people in Chieng So commune did not have any other livelihood activities. There is no room or space to expoit the natural resource due to the disadvantage of geological conditions, no forests, no trees and mostly bare mountainside instead, their natural habitat loss. Furthermore, the Ma river becomes a dead river in winter and dry season, and in rainy season the river becomes red water without any fishs can be able to exist under that condition. Famous handicrafts have been decreased and gradually disappeared,... 
Their habitat loss, material and cultural life of the Xinh Mun ethnic group is going up to the red line at the highest alarming level. Therefore, it is needed to have urgent interventions or projects for making a positive change, ensuring material and cultural life of mentioned Xinh Mun ethnic group.

\section{ACKNOWLEDGMENT}

The research paper was developed within the Master dissertation namely "Changes on culture and livelihoods of the Xinh Mun minority ethnic group at Dien Bien Dong district, Dien Bien province, Vietnam".

\section{REFERENCES}

[1] Hoang Cam, Pham Quynh Phuong, 2012. "Discourse, policy and change of culture and livelihood of ethnic groups”. Institute for Studies of Society, Economy and Environment, 2012.

[2] Tran Tien Khai, Nguyen Ngoc Danh, 2012. "Livelihood and Poverty in Rural Areas of Vietnam". Scientific Report. Ho Chi Minh University of Economics, 2012.

[3] Chu Thuy Lien, 2013. "The Roles of traditional culture of Thai ethnic in Dien BienProvince in the period of integration and development". Research study. Provincial Department of Science and Technology of Dien Bien, 2013.

[4] Nguyen Van Manh, 2009. “Current Cultural Transition of Ethnic Minorities in Quảng Bình”. Journal of Science. Hue University, No 54, 2009.

[5] Ngo Quang Son, 2014. "Developing Models of Improving Sustainable Livelihood for Local Community Based on Prospective Indigenous Knowledge of Ethnic Minorities". Proceedings at International Conference of "Sustainable Development and Poverty Reduction for Ethnics Minorities in Mountainous Areas". Thai Nguyen University Publishing House, 2014.

[6] Chieng So CPC, 2014. "Proposal on new rural development of Chieng So commune (Dien Bien Dong district, Dien Bien Province) period of 2015-2017, vision of 2020”.

Citation: Duong Van Son. "Negative Changes on Culture and Livelihoods of Xinh Mun Ethnic Group (Case Study in Chieng so Commune, Dien Bien Dong District, Dien Bien Province, Vietnam)". International Journal of Political Science (IJPS), vol4, no.3, 2018, pp.36-41. doi: http://dx.doi.org/10.20431/2454-9452.0403005.

Copyright: (C) 2018 Authors. This is an open-access article distributed under the terms of the Creative Commons Attribution License, which permits unrestricted use, distribution, and reproduction in any medium, provided the original author and source are credited. 